\title{
Red scarlett potato yield when using elements of a biological agriculture system on gray forest soil of the middle Volga region forest steppe
}

\author{
Konstantin V. Vladimirov ${ }^{1}$, Anna N. Kshnikatkina ${ }^{2}$, Vladimir P. Vladimirov ${ }^{3, *}$, and Antonina A. Mostyakova ${ }^{4}$ \\ ${ }^{1}$ Tatarsky Center of Agrochemical Service, 420064 Kazan, Russia \\ ${ }^{2}$ Penza State Agrarian University, 440014 Penza, Russia \\ ${ }^{3}$ Kazan State Agrarian University, 420015 Kazan, Russia \\ ${ }^{4}$ Kazan Federal University, 420008 Kazan, Russia
}

\begin{abstract}
The features of the formation of productivity of potatoes of the Red Scarlett variety were studied during cultivation against the background of applying different combinations of organic, mineral, sideral fertilizers and straw in the conditions of the forest-steppe of the Middle Volga. The studies were carried out in the field experiment in 2014-2016 on gray forest soil with medium loam particle size distribution, on the experimental field of the Department of Plant Growing and Horticulture at KSAU. The humus content in the soil of the experimental plot was 3.48-3.65\% (according to Tyurin), labile phosphorus amounted to 128-135, exchange potassium amounted to $152-165 \mathrm{mg} / \mathrm{kg}$ of soil (according to Kirsanov), $\mathrm{pH}$ of the salt extract was 5.5-5.6. The experiments were performed on eight grounds with mineral nutrition. The potato yield in the reference ground due to natural fertility was $18.26 \mathrm{t} / \mathrm{ha}$. Separate application of mineral fertilizers in a dose of N60P60K90 over an average of three years increased the tuber yield as compared to the reference of 10.19 ha, while the introduction of $60 \mathrm{t} /$ ha of manure increased the yield by $8.95 \mathrm{t} / \mathrm{ha}$. Using a traditional fertilizer system (N60P60K90 $+60 \mathrm{t}$ of manure), the yield was $34.95 \mathrm{t} / \mathrm{ha}$. As a result of the transition to the biological fertilizer system (background + green manure + straw), the yield increased to $36.26 \mathrm{t} / \mathrm{ha}$, which is $1.31 \mathrm{t} / \mathrm{ha}$ higher compared to the traditional fertilizer system. On average, over 3 years, the maximum tuber yield of 37.48 t/ha was obtained by applying mineral and organic fertilizers, as well as straw. Sidereal fertilizers and straw provided an increase in the yield of tubers of $7.81 \mathrm{t} / \mathrm{ha}$. The best results for the dry matter content $(22.05 \%)$ and starch $(16.04 \%)$ were demonstrated by tubers from the reference variant. More protein $(2.95 \%)$ and vitamin C $(21.24 \mathrm{mg} \%)$ contained in tubers from the variant when mineral fertilizers were applied in a dose (N60P60K90-background) + green manure + straw
\end{abstract}

\section{Introduction}

Five main periods are distinguished in the development of potato plants. The first period is from the germination of tubers to the emergence of seedlings. With the onset of the biological minimum temperature in the tuber, the intensity of respiration increases, starch turns into sugar, which moves along the vascular bundles to the eyes. The buds of the eyes swell and germinate. The eyes of the apical part of the tuber are more viable and germinate earlier than the lower ones. This phenomenon is called the dominance of the apex (apical germination). To obtain more shoots, apical shoots should be removed before the seed potato tubers are germinated.

The second period proceeds from the appearance of seedlings to the beginning of the formation of generative organs. At this time, the root system, stems and leaves rapidly form. The third period is from the appearance of buds to flowering. During this period, stolons form, at the ends of which thickenings form, which subsequently form young tubers. At the same time, intensive growth of the aboveground mass continues. Plants require the most moisture and nutrients.

The length of time from seedling emergence to the onset of tuber formation depends on many factors. These include: variety, physiological age of seed tubers, daylight hours and temperature. Tuber formation usually begins 3-5 weeks after emergence. One stem forms from 2.5 to 4.5 tubers, the mass of which is from 90 to $400 \mathrm{~g}$. Therefore, it is so important to keep each stem in the bush.

As previously noted, the number of stems depends on the mass of the seed tuber, the number of sprouts, the physiological state of planting material, and the use of effective agricultural technology. The optimal density of the main stems is $200-220 \mathrm{~K}$ per ha. The fourth period is flowering before the beginning of withering tops. The average daily weight gain of tubers reaches $1-1.5 \mathrm{t} / \mathrm{ha}$, and in favorable years $2-2.5 \mathrm{t} / \mathrm{ha}$. The fifth period is from the beginning of the death of the tops to the physiological maturation of tubers.

\footnotetext{
*Corresponding author: Vladimirov_53@bk.ru
} 
From gradually fading tops, a significant part of the nutrients goes into tubers. The accumulation of starch and dry matter in the tubers is nearing completion. Tubers reach physiological ripeness and pass into a state of natural rest [1].

Potato plants during their growth and development are in interaction with external conditions. Knowledge of the characteristics of the growth and development of plants, their requirements for heat, moisture, light, food, air allows successfully applying various agricultural techniques to obtain high yields of this crop.

Potato is a temperate plant. Tubers begin to germinate at a temperature of $5-60{ }^{\circ} \mathrm{C}$. Seedlings appear at $7-8{ }^{\circ} \mathrm{C}$. A favorable temperature for germination is $17-18^{\circ} \mathrm{C}$. In moderately moist soil at a soil temperature of $10-12{ }^{\circ} \mathrm{C}$, seedlings appear on $25-27$ days and at $14-16^{\circ} \mathrm{C}$ on day $18-22$. At low and too high temperatures $\left(31^{\circ} \mathrm{C}\right)$, the rate of germination of potatoes slows down. Germinated tubers sprout 7-10 days earlier.

Potato seedlings develop better in cool, wet weather. The maximum sprouts of tops are observed at a temperature of $17-22{ }^{\circ} \mathrm{C}$. Tops are damaged at minus $1-1.5^{\circ} \mathrm{C}$. Flowering occurs best at a temperature of $18-21^{\circ} \mathrm{C}$, the optimum soil temperature for tuberization is $16-19{ }^{\circ} \mathrm{C}$. At temperatures below $6{ }^{\circ} \mathrm{C}$ and above $23{ }^{\circ} \mathrm{C}$, the tuberization process slows down, and at $2{ }^{\circ} \mathrm{C}$ and above $29^{\circ} \mathrm{C}$ it stops. This is explained by a violation of physiological activity in plants, expressed in enhanced oxidative processes. For the full development of plants, a sum of temperatures above $10{ }^{\circ} \mathrm{C}$ is required for the growing season for early varieties on average of $1000-1200{ }^{\circ} \mathrm{C}$.

Potatoes are demanding about soil moisture. Its transpiration coefficient is $400-500$. At the beginning of the germination of tubers and the emergence of seedlings, plants consume little water, the need for moisture is covered by the mother tuber. The critical period in moisture demand is the phase of the beginning of budding-flowering. The optimum soil moisture during this period should be $70-80 \%$ of the field moisture capacity (FMC) and 60-65\% of the FMC during the period of dying tops and accumulation of starch in tubers.

Potato's need for moisture depends on the variety. According to A.G. Lorkh, the yield of early-growing potato tubers is determined by precipitation in JulyAugust-September. The absence of precipitation at this time is not compensated by their precipitation in other months.

Potato makes high demands on the air regime. For the normal development of stolons and tubers, the oxygen concentration in the soil should be at least $20 \%$ of the volume of soil air. When the oxygen concentration in the soil is up to $5 \%$, stolon and tuber formation stops. The daily need for root oxygen is about $1 \mathrm{mg}$ per $1 \mathrm{~g}$ of dry matter.

On well-treated soils, the porosity reaches $65 \%$ of the soil volume. The looser the soil, the greater the transparency and air intensity. In loose soils, gas exchange between soil and atmospheric air proceeds better. In order to have a sufficient amount of oxygen in loamy soil, it is necessary to maintain it in a loose state with a bulk density of not more than $1-1.2 \mathrm{~g} / \mathrm{cm}^{3}$.

Potato is a photophilous plant. With a lack of light, plants stretch, flowering is disturbed, the tops turn yellow. The productivity of photosynthesis decreases, few tubers are formed, and the yield decreases [1].

Long days are most favorable for the development of potato tops, and tuberization is better with a short day. At more uniform illumination of plants throughout the day, the tops remain more vital increasing the utilization rate of physiologically active radiation. For seed purposes, in order to increase the resistance of tubers to diseases and plant productivity, landscaping is used. In the light, the potato tubers turn green, chlorophyll and the poisonous alkaloid (solanin) are formed in them.

A large role in increasing the yield and quality of tubers belongs to the variety and agricultural techniques of cultivation [2,3]. To obtain high yields and good quality tubers, they must be available to plants on time, in the required quantity and in the right form [4-10]. Potato is a valuable food product. Its tubers contain all the necessary nutrients: carbohydrates, high-quality proteins, vitamins, essential amino acids, organic acids, mineral salts. Therefore, in many countries of the world, including the Russian Federation, the importance of potatoes is constantly growing.

Currently, increasing the yield of this crop through the effective use of growth and development factors is a very topical issue. Indispensable in conditions of limited energy resources is the preservation and increase of soil fertility. In potato growing with a large removal of nutrients from the soil, high mineralization of the organic matter of the soil, this problem is of particular relevance.

The need to transfer the technology of production of potatoes on a biological basis is particularly pronounced. To do this, it is necessary to revise the existing traditional elements of agriculture and develop biological farming. The theoretical justification of the biological (biodynamic) farming system was given by Rudolf Steiner (England) in as early as 1924. In the years 70-80, it became widespread in Western Europe and the United States.

The main objective of the system is to obtain highquality food. Of course, relying solely on the methods of biological farming in its pure form is not realistic. At the present stage of agriculture, the natural sources of nutrient intake do not compensate for the alienation of nutrients from crop yields. Potatoes are particularly demanding on the supply of plants with nutrients. When planning high yields for targeted regulation of the nutritional regime of soils, it is necessary to introduce mineral and organic fertilizers.

Of the nutrients in the formation of high potato yields, nitrogen fertilizers occupy a special place. Their share in this process is about $20 \%$. Lack of nitrogen leads to a decrease in the yield of potato tubers due to premature death of the tops. However, when nitrogen is added above the optimum, it leads to excessive development of the aerial mass, inhibits the development of tubers, and the yield and quality of tubers decreases. 
The role of phosphorus in the life of potato plants is extremely large. It is necessary to obtain high yields, a positive effect on the taste, ripening time and density of the peel of tubers. Thanks to phosphorous, the quality of tubers improves.

Potassium is needed for potatoes to regulate the formation, movement, accumulation and conversion of carbohydrates. Potassium fertilizers have a great influence on the quality of potato tubers [4]. They help increase the content of vitamin $\mathrm{C}$, reduce the probability of black spotting of the pulp of tubers, and discoloration of the raw pulp.

The main organic fertilizer is manure. It enriches the soil with beneficial microflora, promotes the accumulation of humus, improves physical properties, structure, water and air conditions, while increasing the absorption capacity of the soil and its buffering capacity. V.F. Maltsev and M.K. Kayumov [1] note that when $30 \mathrm{t} / \mathrm{ha}$ of manure is introduced into the soil, $100-200 \mathrm{~kg} / \mathrm{ha}$ of $\mathrm{CO}_{2}$ is released daily. To ensure potato yields of $30-40 \mathrm{t} / \mathrm{ha}, 200-300 \mathrm{~kg}$ of $\mathrm{CO}_{2}$ are required daily.

The purpose of our research is to study the features of the formation of Red Scarlett potatoes with traditional $\left(\mathrm{N}_{60} \mathrm{P}_{60} \mathrm{~K}_{90}+60\right.$ t/ha of manure as background $)$ fertilization, transition to biological fertilization (background + green manure+ straw) and biological (manure + green manure + straw) fertilization backgrounds in the forest-steppe of Middle Volga.

In the context of agricultural biologization, the role of plant nutrition diagnostics is even more important. Establishing the level of supply with nutrition elements will allow making appropriate adjustments to the use of basic fertilizer (organic) and using low standards of mineral fertilizers for fractional application (top dressing). However, it requires a choice of forms of mineral fertilizers that are well absorbed by crops and do not adversely affect soil properties and product quality. Diagnostics can refer to soil and plants. The latter, in turn, is represented by leaf and tissue diagnostics.

Soil diagnostics are carried out by generally accepted agrochemical methods, and tissue diagnostics of plants is carried out on fresh samples without ashing.

When determining inorganic forms of compounds in plant tissues, it is necessary to take into account that fast enzymatic transformations of substances occur in them, especially when wilting. Therefore, sampling in the field must envisage a refrigerating vessel, and analyzes should be performed immediately. This circumstance complicates their implementation, especially since insufficiently accurate express methods are used for analyzes.

Leaf diagnostics is performed with ashing of plant material, and pre-selected plant samples can be fixed, if they cannot be analyzed immediately. Instrumental methods are used for chemical analysis: emission spectral analysis, atomic absorption and activation methods, infrared spectroscopy, X-ray fluorescence method and etc.

Based on the analysis, the contents of macro- and microelements in plants (whole plants or leaves) were graded. Such graded contents for nitrogen, phosphorus and potassium (total content) are presented in the table.

Table 1. Graded content of macroelements in potatoes (according to V.V. Tserling, 1990)

\begin{tabular}{|c|c|c|c|c|c|c|}
\hline \multirow[t]{2}{*}{ Element } & \multirow[t]{2}{*}{ Phase, period } & \multirow[t]{2}{*}{ Indication organ } & \multicolumn{4}{|c|}{ Content grade } \\
\hline & & & Very low & Low & Optimal & High \\
\hline Total nitrogen & $\begin{array}{l}\text { Shoots 6-7th leaf } \\
\text { Budding }\end{array}$ & $\begin{array}{l}2-3 \text { rd leaf } 4 \text { th leaf } \\
\text { from top } \\
4-5 \text { th leaf from } \\
\text { top }\end{array}$ & $\begin{array}{l}<4.0 \\
<3.0\end{array}$ & $\begin{array}{c}4.0-4.2 \\
3.5\end{array}$ & $\begin{array}{l}4.5-6.0 \\
4.5-5.0\end{array}$ & $\begin{array}{l}>7.0 \\
>5.0\end{array}$ \\
\hline $\begin{array}{l}\text { Total } \\
\text { phosphorus }\end{array}$ & $\begin{array}{l}\text { Shoots } \\
6-7 \text { th leaf } \\
\text { Budding }\end{array}$ & $\begin{array}{l}2-3 \text { th leaf } 4 \text { th leaf } \\
\text { from top } \\
\text { 4-5th leaf from } \\
\text { top }\end{array}$ & $\begin{array}{l}<0.3 \\
<0.25 \\
<0.2\end{array}$ & $\begin{array}{c}3 \\
0.3-0.36 \\
0.3-0.38\end{array}$ & $\begin{array}{c}0.4-0.5 \\
0.40-0.50 \\
0.40-0.60\end{array}$ & $\begin{array}{l}>0.6 \\
>0.50 \\
>0.65\end{array}$ \\
\hline Total potassium & $\begin{array}{l}\text { Beginning of } \\
\text { flowering }\end{array}$ & $\begin{array}{l}\text { Upper developed } \\
\text { leaves }\end{array}$ & $<0.5$ & $0.5-0.7$ & $0.8-3.0$ & $>3.0$ \\
\hline
\end{tabular}

Research tasks:

- to study the effect of various combinations of organic, mineral, green manure and straw on the yield of potatoes of the Red Scarlett variety;

- to determine the main indicators of the quality of tubers (the content of NPK, dry matter, starch, vitamin $\mathrm{C}$, nitrates).

\section{Conditions, materials and research methods}

The studies were carried out in 2014-2016 on the experimental field of Kazan SAU. Meteorological conditions of vegetation periods from May to August 2014-2016 were characterized by instability in precipitation, with a slight increase in temperature. In 2014, in June, the average monthly temperature was $17.5^{\circ} \mathrm{C}$; precipitation was more than the norm, $162 \mathrm{~mm}$. In general, during the growing season, the average temperature was $17.7^{\circ} \mathrm{C}$; precipitation was $396 \mathrm{~mm}$. In 2015 , in June, the average monthly temperature was $20.8{ }^{\circ} \mathrm{C}$; precipitation was $33 \mathrm{~mm}$ below the norm. In general, during the growing season, the average temperature was $17.3^{\circ} \mathrm{C}$, precipitation was $182 \mathrm{~mm}$, which is $32 \mathrm{~mm}$ lower than normal. In 2016, precipitation in July and August was well below normal. However, due to the fact that irrigation was used in the experiments, potato plants were provided with moisture in all years.

The soil was gray forest with medium loamy granulometric composition. In terms of agrochemical 
parameters the soil contained: $3.48-3.65 \%$ of humus, 128-135 of mobile phosphorus, 152-165 mg of exchange potassium per $1 \mathrm{~kg}$ of soil; exchange acidity was 5.5-5.6.

The predecessor culture was winter wheat. The total area of the plot was $72 \mathrm{~m}^{2}$, accounting area was $60 \mathrm{~m}^{2}$. The medium-fraction tubers $(60-65 \mathrm{~g})$ of the first reproduction were planted. The planting density was 53.2 thousand $\mathrm{pcs} / \mathrm{ha}$ to a depth of $8 \ldots 10 \mathrm{~cm}$. The ridges were cut in spring with a four-row ridge-forming rotary plow with a row spacing of $75 \mathrm{~cm}$. At the same time, the tubers were treated with Prestige KS fungicide (1 1/t, with a solution flow rate of $10 \mathrm{l} / \mathrm{t}$ ).

Zenkor Techno VDG herbicide with a spread rate of $1.2 \mathrm{~kg} / \mathrm{ha}$ was used against weeds. To suppress late blight, the Ridomil Gold MC systemic fungicide $(2.5 \mathrm{~kg} / \mathrm{ha})$ and copper-containing preparations were used.

Manure, green manure and straw were introduced by autumn plowing. Mineral fertilizers during planting.

\section{Experimental scheme}

1. Without fertilizers (reference).

2. $\mathrm{N}_{60} \mathrm{P}_{60} \mathrm{~K}_{90}$ (background).

3. Manure $60 \mathrm{t} / \mathrm{ha}$.

4. Background + manure 60 t/ha.

5. Background + green manure.

6. Background + green manure + straw .

7. Background + manure + straw.

8. Manure + green manure + straw .

\section{Results and discussion}

Tuber productivity on all variants of the experiment was higher in 2014. Fertilizing in all years of research provided a significant increase in yield on all variants of the experiment.

The highest tuber yield (37.48 t/ha) was when organic and mineral fertilizers were combined with straw, and the yield increased by $19.22 \mathrm{t} /$ ha compared to the reference variant (see Table 1). This is due to the fact that organic fertilizers are mineralized slowly, nutrients are difficult to digest and are used less productively in the initial period of plant growth. In mineral fertilizers, nutrients are contained in a readily available form and are better used in the early period.

The application of separate mineral fertilizers in a dose of $\mathrm{N}_{60} \mathrm{P}_{60} \mathrm{~K}_{90}$ over an average of three years increased the productivity of tubers by $10.19 \mathrm{t} / \mathrm{ha}$, and the use of manure in a dose of $60 \mathrm{t} / \mathrm{ha}$ added $8.95 \mathrm{t} / \mathrm{ha}$. Tillage of green manure fertilizer in the form of blue lupine and additional mineral fertilizers as $\mathrm{N}_{60} \mathrm{P}_{60} \mathrm{~K}_{90}$ increased the yield compared to the reference by $14.58 \mathrm{t} / \mathrm{ha}$.

When using variant 8 , the biological fertilizer system (manure $60 \mathrm{t} / \mathrm{ha}+$ siderate + straw), the yield was $34.36 \mathrm{t} / \mathrm{ha}$. The maximum yield of $37.48 \mathrm{t} / \mathrm{ha}$ was obtained using the variant "background + manure + straw", while the gain compared to the reference variant was $19.22 \mathrm{t} / \mathrm{ha}$.

Table 2. Yield of potatoes of the Red Scarlett variety, depending on background nutrition ( $\mathrm{t} / \mathrm{ha}$ )

\begin{tabular}{|l|c|c|c|c|c|}
\hline \multirow{2}{*}{ Variant } & \multicolumn{4}{c|}{ Crop capacity [t/ha] } & \multirow{2}{*}{$\begin{array}{c}\text { to reference } \\
\text { variant }\end{array}$} \\
\cline { 2 - 5 } & 2014 & 2015 & 2016 & moderate & - \\
\hline 1. No fertilizers (reference) & 19.26 & 18.22 & 17.3 & 18.26 & +10.19 \\
\hline 2. N60 ${ }_{60} K_{90}$ (background) & 31.45 & 29.25 & 24.65 & 28.45 & +8.95 \\
\hline 3. Manure 60 t/ha & 30.14 & 28.33 & 23.16 & 27.21 & +16.69 \\
\hline 4. Background + manure 60 t/ha & 38.25 & 35.12 & 31.48 & 34.95 & +14.58 \\
\hline 5. Background + green manure & 35.24 & 33.67 & 29.61 & 32.84 & +18 \\
\hline 6. Background + green manure + straw & 38.12 & 36.96 & 33.7 & 36.26 & +19.22 \\
\hline 7. Background + manure + straw & 39.44 & 38.32 & 34.68 & 37.48 & +16.1 \\
\hline 8. Manure + green manure + straw & 36.54 & 35.26 & 31.28 & 34.36 & \\
\hline LSD 05 & 1.44 & 1.49 & 1.28 & & \\
\hline
\end{tabular}

The analysis of experimental data showed that the content of dry matter, starch, crude protein, vitamin $\mathrm{C}$ and nitrates in the tubers of the studied variety varied significantly depending on the level of mineral nutrition.

In the dry matter of potato tubers, starch occupies a significant part. More dry matter $(22.05 \%)$ was contained in tubers from the reference variant, where fertilizers were not applied. Depending on the variant of the experiment on fertilized variants, the dry matter content ranged from 20.59 to $21.86 \%$.

On average, over three years, the highest content of vitamin C (21.24 mg \%) was observed in tubers with the variant with background fertilizers $\left(\mathrm{N}_{60} \mathrm{P}_{60} \mathrm{~K}_{90}\right)+$ green manure + straw, and the smallest (18.21 mg \%) content was observed in the control variant without fertilizing.

One of the reasons for the accumulation of excess nitrates in tubers is the use of high doses of mineral and organic fertilizers for potatoes. In our experiments, the rational use of fertilizers, especially of organic origin, did not lead to a significant increase in the amount of nitrates in tubers. Indeed, tubers from the control variant contained a smaller amount of nitrates $(58.56 \mathrm{mg} / \mathrm{kg})$. In tubers of variant 8 , where manure, green manure and straw were added, their amount increased by only $2.89 \mathrm{mg} / \mathrm{kg}$.

Potato protein, due to the optimal ratio of essential amino acids, has significant biological value. Over the three years, in experimental variants, no significant difference in the protein content in potato tubers had been established. Less protein was contained in the reference variant, and more of that, after the introduction of background fertilizers, green manure and straw. The amount of starch was greater in the reference variant $(16.05 \%)$. In other variants, the amount of starch did not 
differ significantly and, depending on the nutritional background, the decrease was from 0.26 to 0.8 percent.

A large degree of tuber damage with late blight $(4.4 \%)$ was observed in the reference variant. Introduced fertilizers reduced potato damage by late blight by $0.5-1.4 \%$. Tubers from variant 6 were less affected where mineral fertilizers, green manure and straw were introduced. Dry rot damage ranged from $0.1 \%$ against the background of the application of mineral and green manure fertilizers to $0.6 \%$ in the reference variant. The content of tubers affected by wet rot ranged from 0.1 to $0.3 \%$, and on variants where green manure was used together with other species, it was not observed.

Growing high reproduction potatoes predetermined a low percentage of natural loss and ensured high preservation of tubers. Depending on the variant, it amounted to $91.8-92.9$ percent during the storage period.

\section{Conclusion}

According to the effective fertility of the gray forest soils of the experimental field, an average yield of $18.26 \mathrm{t} / \mathrm{ha}$ for three years was formed. Separate application of mineral fertilizers $\left(\mathrm{N}_{60} \mathrm{P}_{60} \mathrm{~K}_{90}-\right.$ background $)$ increased the productivity of tubers by $10.19 \mathrm{t} / \mathrm{ha}$, while manure $(60 \mathrm{t} / \mathrm{ha})$ increased it by $8.95 \mathrm{t} / \mathrm{ha}$. With mineral fertilizers $\left(\mathrm{N}_{60} \mathrm{P}_{60} \mathrm{~K}_{90}\right.$ - background), green manure and straw, the potato yield was $36.26 \mathrm{t} / \mathrm{ha}$. The share of green manure and straw was $7.81 \mathrm{t} / \mathrm{ha}$ or $27.4 \%$. The highest tuber yield (37.48 t/ha) was obtained in the variant where mineral fertilizers $\left(\mathrm{N}_{60} \mathrm{P}_{60} \mathrm{~K}_{90}-\right.$ background $)$, organic fertilizers and straw were applied. The best indicators for the dry matter content $(22.05 \%)$ and starch $(16.05 \%)$ were tubers from the control variant. More protein $(2.95 \%)$ and vitamin C (21.24 $\mathrm{mg} \%)$ contained tubers from variant 6 where mineral fertilizers, green manure and straw were applied.

\section{References}

1. V.F. Maltsev, M.K. Kayumov, Biological System of Agriculture in the Non-Black Earth Zone of Russia, vol. 2 (Rosinformagrotekh, Moscow, 2002)

2. Z.I. Usanova, N.V. Samotaeva, V.V. Filin, G.V. Kisileva et al., The theory and practice of creating highly productive plantings of potatoes in the Central Non-Chernozem region (Triada, Tver, 2013)

3. Z.I. Usanova, V.N. Filippov, Potato cultivation technology in the Upper Volga region, Potat. and vegetabl., 3, 5-6 (2008)

4. D. Shpaar, A. Bykin, D. Draeger, Potatoes. Growing, harvesting, storage (DLV AGRODELO, Moscow, 2016)

5. S.V. Vladimirov, Effectiveness of increasing doses of mineral and organic fertilizers when growing potatoes in the forest-steppe of the Middle Volga region, Bull. of the Kazan State Agrar. Univer., 3(29), 92-95 (2013)

6. A.N. Postnikov, I.F. Ustimenko, E.A. Bolotnova, Productivity and quality of potatoes when using the zircon preparation on various nutritional backgrounds, Achievem. of sci. and technol. of the agro-industr. complex, 6, 57-58 (2012)

7. A.E. Shabanov, A.I. Kisilev, N.S. Zebrin, Productivity and quality of new varieties of potatoes, depending on the methods of agricultural technology, Achievem. of sci. and technol. of the agro-industr. complex, 01, 30-31 (2011)

8. T.I. Burmistrova, L.N. Sysoeva, T.P. Alekseeva et al., Studying the effectiveness of the use of organic fertilizers in growing potatoes, Achievem. of sci. and technol. of the agro-industr. complex, 5, 32-33 (2012)

9. A.A. Mostyakova, V.P. Vladimirov, I.R. Gareev, N.V. Sitnikova, Ways to increase the use of photosynthetic active radiation by early ripening varieties of potato in Middle Volga Region Russia, Biol. and Med. Res. Article, 7(1), Article ID: BM066-15, 1-7 (2015)

10. A.A. Mostyakova, K.V. Vladimirov, V.P. Vladimirov, U.A. Ogorodnova, Efficiency of Different Fertilizers Doses Introduction Under Potatoes On Grey Forest Of The Tatarstan Republic, Res. J. of Pharmac., Biolog. and Chem., RJPBCS, 7(6), 3283-3290 (2016)

11. V.F. Maltsev, M.K. Kayumov, Biological System of Agriculture in the Non-Black Earth Zone of Russia, vol. 2 (Rosinformagrotekh, Moscow, 2002) 